Dr ZORAN JANJETOVIĆ, naučni savetnik

Institut za noviju istoriju Srbije

Beograd, Trg Nikole Pašića 11, Republika Srbija

e-mail: vanilica@ptt.rs

pregledni rad

UDK: 94(497.1)"1939/1945"

primljeno: 31. jul 2017.

prihvaćeno: 15. novembar 2017.

329.18:929 Љотић Д. В.

DOI: 10.29362/IST20VEKA.2018.1.JAN.93-118

\title{
DIMITRIJE LJOTIĆ AND WORLD WAR II*
}

\begin{abstract}
Based on memoirs, historiographical works and archival sources, the article deals with the role of the contraversial right-wing politician and the leader of the Zbor movement during WWII. His ideology and its changes before the war were depicted in order to present his wartime activities. Under occupation he became one of the leading and most influential collaborationists and the only one to wield his own armed forces. Although small they played significant role in struggle for power and against the communist-led partisans. The wartime conditions forced him to relinquish some of his lofty principles. It is shown how he remained true to his strongest convictions until the end: Yugoslavism and anti-Semitism.
\end{abstract}

KEYWORDS: Dimitrije Ljotić, Zbor, WWII, occupation, Jews, Germans, Milan Nedić

It is difficult to say much new about this topic. Most of the sources for it have been known for decades and the new ones that appeared during the last couple of years (above all the documents the Serbian inteligence service, the BIA, has declassified couple of years ago) usually tell less about Ljotić in person, and much more about his entourage. Nevertheless, in this paper we will present - in our opinion objective - picture of his role in the largest armed conflict in history: the role that has been much too often judged from dyametrically opposed ideological standpoints. ${ }^{1}$

\footnotetext{
* The article came into being as part of the project no. 47027 financed by the Ministry of Education, Science and Technological Development of the Government of the Republic of Serbia.

${ }^{1}$ The bulk of literature on this controversial politician is polemically tinged. While he had been extalled by the publicists of the Zbor, the communist historiography had denigrated him as fascist and ordinary mercenary of the occupiers. (Cf. above all: Ratko Parežanin, Drugi svetski rat i Dimitrije V. Ljotić (Beograd: A. Z. Jelić, P. Janković, 7510 (sic.); Milutin Propadović, D. V. Ljotić, Zbor i Komunistička partija Jugoslavije 1934-1945. Prilozi za istinu o JNP Zbor (Beograd: Iskra, 2012); Mladen Stefanović, Zbor Dimitrija Ljotića 1934-1945 (Beograd: Narodna knjiga, 1984). Probably the only attempt at dealing with this topic impartially can be found in the book by a former member of the Zbor, Mirko Bojić, Jugoslovenski narodni pokret ,Zbor “ 1935-1945: Jedan kritički prilaz [Beograd: Zakoni života-Svetlo istine], 1996.
} 
As a rule, Ljotić's Zbor-movement has been assessed fascist or profascist in the older Serbian historiography. ${ }^{2}$ Ljotic himself and his collaborators vehemently denied it already in 1930s. ${ }^{3}$ We are inclined to make allowances for all differences Ljotic and the members of the Zbor had adduced in their defense, but due to certain similarities with fascist movements, ${ }^{4}$ we deem that the Zbor can in any case be regarded as extremely right-wing oriented. ${ }^{5}$ The question if the Zbor had been or had not been a fasicst movement is important for our topic inasmuch the whole explanation of Ljotic's and the Zbor's role in WWII offered by communist historians and theoreticians was based on assertion that the Zbor had been a fascist movement, so that it was allegedly all too natural that it had ,started serving the occupiers" during the occupation of Serbia. ${ }^{6}$ Ideological similarities and very sporadic contacts with German and Italian representatives before the war, were adduced as additional proof of allegedly premeditated collaboration. Furthermore, the collaboration was projected into the pre-war period and the Zbor accused of preparing and aiding German agression. ${ }^{7}$

${ }^{2}$ Branislav Gligorijević, „Osobenosti fašizma u Jugoslaviji dvadesetih godina“, Marksistička misao, 3, (1986), 35, 41; Idem, „Politički pokreti i grupe s nacionalsocijalističkom ideologijom i njihova fuzija u Ljotićevom „Zboru“““, Istorijski glasnik, 4, (1965); Todor Kuljić, Fašizam: Sociološko-istorijska studija (Beograd: Nolit, 1987 (2nd ed.)), 228-252; Žarko S. Jovanović, Neostvareni ratni ciljevi Draže Mihailovića u Srbiji 1941-1945 (Beograd: INIS, 2001), 27. (This author calls the Zbor a ,pro-fascist organization" on p. 71.) In a way, that was the opinion of German diplomats in Belgrade too. (Cf. Ernst Nolte, Die Krise des liberalen Systems und die faschistischen Bewegungen (München: Piper, 1968), 246.) The authors of the comprehensive collection of papers Who Were the Fascists, did not include Ljotić's Zbor among the fascist movements of Europe - unlike the Ustasha (Cf. Stein Ugelvik Larsen, Bernt Hagtvet, Jan Petter Myklebust, (eds.), Who Were the Fascists. Social Roots of European Fascism (Bergen, Oslo, Tromsø: Universitetsforlaget, 1980), although two of the authors did mention him as fascist. (Ibid., 352, 756, 763.) One of the greatest experts on fascism, Stanley Payne, defined the Zbor as a radical rightwing movement. (Stanley G. Payne, A History of Fascism 1914-1945 (London, New York: Routledge, 2003), 15, 186-190, 325.) However, he deems the Zbor evolved during WWII in Serbia and has become more clearly similar to fascist movements. (Ibid., 428.)

${ }^{3}$ Dimitrije Ljotić, Sabrana dela (henceforth: SD), VI (Beograd: Nova iskra, 2001), 206; M. Propadović, op. cit., 30-40, 270-272; R. Parežanin, op. cit., 128-134.

${ }^{4}$ Vasilije Dragosavljević, „Ideološki uticaji evropskog fašizma na JNP Zbor (1934-1940)“, Istorijska tribina mladih saradnika, urednik Zoran Janjetović (Beograd: INIS, 2013), 93-108. Dragosavljević shows that the influence of the Action Française was dominant in the begining, until 1936, when the influence of Italian fascism and German national-socialism, embodied primarily in anti-communism and anti-Semitism, became increasingly more pronounced. On differences between the fascist corporativism and Zbor's estates system, cf. M. Propadović, op. cit., 16-27.

${ }^{5}$ It should be kept in mind that there is no precise and generally accepted definition of fascism. (Cf. Constantin Iordachi (ed.), Comparative Fascist Studies. New Perspectives (London, New York: Routldg, 2010), VIII, 1; S. Payne, op. cit., 461; Mikloš Lacko, „Fašizam u istočnoj i srednjoj Evropi: Prilog opštoj definiciji fašizma“, Marksistička misao, 3, (1986), 123.)

${ }^{6}$ The communists accused the Zbor of being „fascists" and the „fifth column“ already before the war. (Petar Martinović-Bajica, Milan Nedić (Čikago: Nikola Pašić, 1956), 345.) Thus the activities of the Zbor under occupation were almost a logical corollary - which was laid down as a dogma already in the materials of the State Commission for Establishing the Crimes of the Occupiers and their Abettors. (Arhiv Jugoslavije (AJ), Državna komisija za utvrđivanje zločina okupatora i njegovih pomagača, 110 , f. $765 ;$ f. 767 , f. 2310 .)

7 AJ, 110-765; 110-767; 110-803. Such unproven claims were adopted by communist historiography. Cf. Branislav Gligorijević, „Napad ljotićevaca na studente Tehničkog fakulteta u Beogradu, 
Without wanting to join Ljotić's apologists, we think that the reality was much more complicated than the picture offered by leftist propagandists, ideologues, historians and sociologists. Ljotić's vision of WWII and his role in it were, no doubt, determined by Ljotić's ideological worldview. However, it does not follow from this irefutable fact, that he was a quisling of common variety who collaborated with the occupiers for ideological or selfish reasons, i. e. that he has ,put himself in the service of the occupiers“. Ljotić, as well as his cousin, General Nedić, had started collaborating with the occupational authorities in order to preserve the Serbian people. Obviously, such a role could not have been taken by persons standing ideologically too far from the occupiers. In other words, certain ideological affinity enabled Ljotić (and partly Nedić too) in the first place to try to influence the occupiers in the interest (such as the two of them saw it) of the Serbian people. This does not mean that with them, as with other collaborationists, other motives were not intermingled - such as wish to reform the society in keeping with their own ideas, love of power, cupidity etc, but they should be established for each person individually.

WWII and the occupation of Yugoslavia demanded of Ljotic that he change some of his views, or at least hide them for the time being. On the other hand, the war additionally radicalised some of his views, or put a new stress on some others. Also, for the first time he was transformed from an ideologue into a practicing politician with conciderable influence on the powers-that-be. Under the wartime conditions fight against ideological oponetnts was turned into a life and death struggle which forced him to break some of his principles. Under occupation, his collaborators did it to a much larger extent, often because of their moral weakness - which did not enhance the esteeme enjoyed by the Zbor and Ljotić personally.

Pursuing watchfully the development of the international relations, Dimitrije Ljotić predicted war already in September $1938 .{ }^{8}$ Writing mostly in his illegal news-sheet, the Bilten - that was written by himself for the largest part - in keeping with his elitist view on power and having been prevented from adressing broad public through the big press, he tried to influence the leading persons to change the policy of the state. He observed the strengthening of the Axis powers. He correctly foresaw that the Soviet Union would not conclude a pact with the Western powers, but with Germany. ${ }^{9}$ Despite some common features with Fascist and Nazi ideologies, he deplored the fate of Czechoslovakia and Poland. ${ }^{10}$ This

u oktobru 1940. i rasturanje Ljotićevog „Zbora““”, Istorijski glasnik, 2, (1963), 53. The same autyhor claims the Zbor had as its main task „to serve the interests of the Axis powers“, only to quote Ljotić's articles in which he champions Yugoslavia's neutrality and a Balkan pact with the aim of preserving it! (Ibid., 53-56).

${ }^{8}$ D. Ljotić, $S D$, XII, 13.

${ }^{9}$ Other members of the Zbor did not believe it expecting an alliance between Paris, London and Moscow. (R. Parežanin, op. cit., 160-161; M. Propadović, op. cit., 84.)

${ }^{10}$ The claim proffered by Branislav Gligorijević that Ljotić hailed the fall of Czechoslovakia is not true. (Cf. B. Gligorijević, „Napad“, 53.) Cf. Ljotić's condamnation of dismemberment of Czechoslovakia in: D. Ljotić, SD, VII, 74, 90. Cf. also the leaflet of the Zbor's youth „Jugoslovenskoj 
mirrored his deep pan-Slav convictions that were part and parcel of his mystic way of thinking. Despite his condamantion of Germany for destruction these two nations ${ }^{11}$ he did not see the main instigator of war in Hitler and his Reich, but in the Jews. ${ }^{12}$ That was the point where his often perspicatious analysis of foreign policy turned into shalow, and in the last extent illogical, anti-Semitic clichees: according to Ljotić, the Jews were the people who systematically strove to gain mastery over the world. ${ }^{13}$ Allegedly, by using the equality they had gradually acquired after the French revolution, they abused it in order to weaken Christian nation-states through democracy, individualism, materialism, capitalism, FreeMasonry and Marxism. ${ }^{14}$ According to Ljotić, these doctrines were destroying organic fabric of nations, pulverizing societies into groups of selfish individuals pursuing their own materialistic interests. By instigating class hatred and using Marxism the Jews had, according to him, gained power in the once Slavic Russia, turning it into the internationalist Soviet Union - the launching pad of the world revolution and their future power over the whole world. ${ }^{15}$ The Soviet leaders allegedly did not want war in 1939 , i. e. they wanted a war in which the USSR would not take part. ${ }^{16}$ The Jews managed to weaken the Western powers ${ }^{17}$ and Hitler, who on first site dealt a blow to the Jews, ${ }^{18}$ was in fact their tool. By starting the war that would weaken both Germany and the Western powers, he would enable the Soviet Union in the later phase of the war, to conquer them all. Therefore, according to Ljotić, it was Stalin who had pushed Hitler into the war. ${ }^{19}$

Ljotić defended (often with good arguments) his views on shortcomings of democracy and capitalsim ever since the begining of the Zbor's activities in 1934. In 1936 he became increasingly anti-Semitic and tended to see the Jews behind all evils of the world he had condamned already before (materialism, individualism, democracy, capitalism, communism). When reading his countles articles on these issues, one cannot help wondering how someone who realized so shrwdly all shortcomings of both demoratic system and its side-kick, capital-

omladini" on that occasion protesting destruction of Czechoslovakia and demanding unification with Bulgaria with the aim of preserving the people and the state. (AJ, 102, 10/25.) On occasion of German attack on Poland in his Bilten no. 27 of September 11, 1939, Ljotić wrote that „the Polish stand“ [i. e. resistence - Z. J.] incited ,sympathies of every man deserving of the name and of every heroic people“. (D. Ljotić, SD, VII, 180.)

${ }^{11}$ M. Propadović, op. cit., 70 .

${ }^{12}$ D. Ljotić, SD, VI, 227; Ibid., VII, 24-25, 48, 66-67, 113; Ibid., VIII, 7; Ibid., IX, 36, 76; Ibid., X, 53, 181; Ibid., XII, 86-92, 103-104, 122-142, 145-152.

${ }^{13}$ D. Ljotić, SD, VI, 90-96; Ibid., VII, 67, 74-75, 113; Ibid., VIII, 71; Ibid., IX, 193-194.

${ }^{14}$ D. Ljotić, SD, V, 22, 59, 145, 147; Ibid., VI, 33, 61, 66, 84, 203-204; Ibid., VIII, 184; Ibid., IX, 72, 80, 170-172, 190; Ibid., X, 81; Ibid., XI, 19, 21-22, 28-55, 58, 65, 69, 90-103.

${ }^{15}$ D. Ljotić, SD, VI, 152-154; Ibid., VIII, 111; Ibid., IX, 44, 41-142, 146; Ibid., X, 174, 194; Ibid., XI, 118; Ibid., XII, 112.

${ }^{16}$ D. Ljotić, SD, VII, 25-26, 42-43, 45-46, 55-56, 66, 74-75, 95, 97, 104-107, 112, 118, 124 , 173; Ibid., VIII, 60-63, 185-186, 200-201.

${ }^{17}$ D. Ljotić, SD, V, 66, 116; Ibid., VII, 79, 108, 148-150, 173; Ibid., VIII, 72; Ibid., IX, 10-12, 63; Ibid., XI, 99; Ibid., XII, 22, 24.

${ }^{18}$ D. Ljotić, SD, VII, 67, 125, 128, 146; Ibid., VIII, 64-65, 89-91; Ibid., XI, 13-18; Ibid., XII, 38, 51.

${ }^{19}$ M. Bojić, op. cit., 133-134; M. Propadović, op. cit., 86; R. Parežanin, op. cit., 161-164. 
ism (esspecially in its Yugoslav variety), and real socialism as built in the USSR, could have accepted such a shallow explanation as the theory of the Jewish world conspiracy. This question should probably be answered by psychologists, and not only in the case of Dimitrije Ljotić, since he was by no means the only one holding such views.

Be that as it may, having seen the „stormy clouds" (as he used to say) aproaching, he devoted most of his political activity during 1939 and 1940 to struggle to keep Yugoslavia out of the world conflict. ${ }^{20}$ Since the Zbor did not manage to have a single MP elected at the elections in 1938 and since the government was incrasingly putting pressure on it, his activity was conducted primarily through speach making and lecturing, but mostly through publications. Ljotić criticized the situation in the country that made it incapable of defense in case of need, as well as its slack foreign policy. Just like in the previous period he strafed the endemic corruption and discord among political parties and the three Yugoslav „tribes“ (i. e. Serbs, Croats and Slovenes). He perceived the main roots of the evil in what he called "two sins": the Serbian and the Croatian one. According to him, the "Serbian sin“ consisted in the fact that the Serbs had left their traditional path of humanity and heroism after 1918, abandoning themselves to all kinds of corruption. The „Croatian $\sin ^{\text {“, was }}$ smaller according to him, and it consisted in the fact that the Croats had spit on the idea of Yugoslavism that had been spawned by their best sons in 19th century. ${ }^{21}$ In that context, he denounced the Cvetković-Maček agreement as the agreement of „two sins", and did not see in it the political act that would strengthen Yugoslavia in the face of foreign manace. ${ }^{22}$ Incompleteness of the agreement and the actual situation seemed to have proven that he had been right. ${ }^{23}$

He perceived the Yugoslav foreign policy as slack, only reacting to events, not forseeing them. Instead, he favored a proactive policy that would be aiemd at forging a Balkan alliance that would be strong enough to guarantee the neutrality of the region. ${ }^{24}$ To that goal, he was willing to make territorial concessions to Bulgaria and Hungary. ${ }^{25}$ Clearly, such policy of neutrality would have to be founded on good relations with Italy, and esepcially with German, the main revisionist power. Ljotić assessed correctly that Germany wanted peace in South-Eastern Europe and that this was the region's chance to

${ }^{20}$ D. Ljotić, SD, V, 112-113, 142, 151, 154-155; Ibid., VI, 211-212, 222; Ibid., VII, 17-18, 2627, 37-38, 49, 91, 126, 130, 153-155; Ibid., VIII, 52, 163-164, 197; Ibid., IX, 24-25, 53; Ibid, XII, 80,85 .

${ }^{21}$ D. Ljotić, SD, V, 152-154; Ibid., VII, 140, 159, 176-180; Ibid., VIII, 75-76, 171, 206-207; R. Parežanin, op. cit., 262-266; Hrvoje Magazinović, Kroz jedno mučno stoljeće: Sjećanja (Valjevo: Novo videlo, 2009 (2nd expanded edition), 112.

${ }^{22}$ D. Ljotić, SD, VI, 212-214, 217-219; Ibid., VII, 109, 139-140, 157-158, 176; Ibid., VIII, 75, 99-100, 111-112; Ibid., IX, 20, 49-52, 92-93, 135; Ibid., XII, 71.

${ }^{23}$ D. Ljotić, $S D$, VIII, 13-15, 42-43, 54-55, 94-97, 174, 190-191, 195.

${ }^{24}$ D. Ljotić, SD, V, 140-142; Ibid., VII, 117-118, 153-155; Ibid., VIII, 52, 82-88, 151-152, 165166, 189, 205; Ibid., IX, 27-28, 45, 77, 97, 105, 201; Ibid., XII, 93.

25 D. Ljotić, SD, VI, 222; M. Bojić, op. cit., 137-138; M. Propadović, op. cit., 61-68; R. Parežanin, op. cit., 174, 236-242, 247. 
stay out of war. ${ }^{26}$ Because of that, it was necessary to smother frictions among Balkan countries and to do away with foreign influences - above all, with British propaganda, for which he, of course, believed was acting in Jewish interest. ${ }^{27}$

As the recipy for preservation of the country's neutrality, and thus its salvation, he proposed disbanding political parties, creating a broad Serbian front that would be strengthened with pro-Yugoslav Croats and Slovenes, giving the reins of power to the best, anulling the Cvetković-Maček agreement, removing the Jews and reforming the army. ${ }^{28}$ According to his plan, only the Serbs, together with nationally conscious (i. e. pro-Yugoslav) Croats, Slovenes and Muslims would serve in it. ${ }^{29}$ Furthermore, it was necessary to smother communist propaganda that, in Ljotic's opinion, acted destructively in the intereast of the USSR. Because of that he vehemently oposed establishing commercial relations with that country, believing this would open the gate wide for Bolshevik propaganda. ${ }^{30}$

He hailed Yugoslavia's accession to the Tripartite Pact as the last means to to save the country from war for which he believed would bring not only defeat, but catastrophy too („Kosovo without Kosovo“ as he used to say - an alusion to heroic defeat of the Serbian army by the Ottomans at Kosovo in 1389). ${ }^{31}$ Unlike some other Zbor members, he condamned the coup d'etat of March 27, 1941, forseeing correctly its consequences, ${ }^{32}$ but in keeping with his patriotism and his duties as an officer in reserve, he loyally answered the call-up.

During the period between September 1939 and April 1941 Ljotić remained true to his old Yugoslavism. He fought tooth and nail to consolidate Yugoslavia and to keep it neutral. His enemies ascribed this to his alleged German-

${ }^{26}$ D. Ljotić, SD, IX, 39, 97, 105, 146-147, 178, 186, 201; Ibid., XII, 95. Ljotić deemed one should turn to Germany to curb Italian aggressive aspirations toward Yugoslavia. (D. Ljotić, SD, VIII, 131, 177.)

${ }^{27}$ Ljotic guessed correctly that France and Britain strove to drag the Balkans into the war with the Axis powers. (D. Ljotić, $S D$, VIII, 196, 205; Ibid., IX, 25-27.)

${ }^{28}$ D. Ljotić, SD, VIII, 169-171; Ibid., IX, 168-169; Ibid., XII, 101, 108; M. Bojić, op. cit., 134-135.

${ }^{29}$ D. Ljotić, SD, VI, 226; Ibid., VII, 17; Ibid., VIII, 50. He never explained the last mentioned demand. In his letter to the Regent, Prince Paul, of August 30, 1940, he said under the term Muslims, he meant the Albanians. (M. Bojić, op. cit., 279; M. Propadović, op. cit., 267.) Considering the difficulties the Yugoslav state had integrating the Albanians, this demand seems puzzling. (Cf. Zoran Janjetović, Deca careva, pastorčad kraljeva: Nacionalne manjine u Jugoslaviji 1918-1941 (Beograd: INIS, 2005), passim; Đorđe Borozan, Velika Albanija. Porijeklo - ideje - praksa (Beograd: Vojnoistorijski institut Vojske Jugoslavije, 1995); Idem, Ljubodrag Dimić (eds.), Jugoslovenska država i Albanci, I-II (Beograd: Arhiv Jugoslavije, 1998-1999.)

${ }^{30}$ D. Ljotić, SD, V, 131-132; Ibid., VI, 219; Ibid., VII, 73; Ibid., VIII, 10-11, 22-26; Ibid., IX, 21-22, 28-31, 62-63, 88, 200; M. Propadović, op. cit., 95; R. Parežanin, op. cit., 248-249.

${ }^{31}$ D. Ljotić, SD, VI, 224; M. Bojić, op. cit., 139-140; R. Parežanin, op. cit., 304. There is also another version according to which he deemed the pact to be a serious political mistake, both for Yugoslavia and for Germany. (H. Magazinović, op. cit., 165). It is not to be excluded that both claims were true at certain points, i. e. that Ljotić has changed his mind over time.

${ }^{32}$ R. Parežanin, op. cit., 284-285, 307. 
friendliness. ${ }^{33}$ However, there was no such thing. Ljotić was not only educated in France, but also a francophile. ${ }^{34}$ On several occasions he condamned some moves of the German foreign policy ${ }^{35}$, for which he believed worked, in the last resort (just like the British one), in favor of the Jewish scheeme to subjugate the world. ${ }^{36}$

The swift defeat of Yugoslavia in April 1941 proved that Ljotic had correctly assessed the defensive capabilities of his country and forseeen the danger threatening it. Dismemberment of Yugoslavia and occupation of Serbia put Ljotića and his Zbor before new tasks under quite new circumstances.

Even thought the Zbor was the only political organization allowed to continue functioning under German occupation, the circumstances under which they had to act had changed. ${ }^{37}$ First of all, the geographical, and partly the ideological framework had changed. There was no Yugoslavia any more. The Germans would not hear of it any more, ${ }^{38}$ whereas the peoples populating it had also turnd their backs on it. It seemed there were no prospects of restoring the common state. In that way, one of the basic features of the movement - Yugoslavism - was dropped with a stroke of a pen. ${ }^{39}$ This was done tacitly and oportunistically, but

${ }^{33}$ There are several testimonies that Ljotic did not trust the Germans and that he disliked them. According to some witnesses Ljotić said of the Germans they were ,people mute in their souls“ (R. Parežanin, op. cit., 317; H. Magazinović, op. cit., 159, 212), whereas, according to an informant's report, he allegedly said of the Gestapo officers they were not humans in the reals sense of the word. (Istorijski arhiv Beograda (IAB), BdS, J 423.)

${ }^{34} \mathrm{He}$ took some of his main ideas over from Charles Maurras, whereas his deeper worldview and way of writing stood very much under the influence of Blaise Pascal whom he greately admired. (D. Ljotić, SD, VII, 78; Ibid., IX, 151; Ibid., XI, 14, 147; M. Stefanović, op. cit., 18-19; M. Bojić, op. cit., 15.) Unlike German that he did not know, he spoke French (Cf. Arhiv Srbije (AS), BIA, II/69; R. Parežanin, op. cit., 513.)

${ }^{35}$ D. Ljotić, SD, V, 111; Ibid., VII, 49, 74, 90; Ibid., IX, 8-9, 35, 42. After the disaster in April 1941 Ljotic believed the German authorities prevented the Serbs from finding their real way. (IAB, BdS, I, reg. br. 35.) According to Parežanin, [probably in 1941] he warned the German authorities they would push both the Russians and the Ukrainians into the communist camp if they did not bring them freedom. (R. Parežanin, op. cit., 507-508.) Apart from that, in the final phase of the war, in spring 1944, he condamned German attitude toward the Serbs and the Russians (M. Bojić, op. cit., 160; H. Magazinović, op. cit., 230, 236).

${ }^{36} \mathrm{He}$ wrote on several occasions that British policy had been directed by the Jews (D. Ljotić, SD, IX, 128; Ibid., X, 60, 104, 131).

${ }^{37}$ Ljotić asked of the Field Command 599 on May 22, 1941 permission for the Zbor to continue operating and was granted it three days later. (Milan Borković, Kontrarevolucija u Srbiji, I (Beograd: Sloboda, 1979), 165.) Under wartime conditions, the movement's organization was reduced to a minimum and new members were not accepted. (Cf. M. Bojić, op. cit., 155-156.) The claim by Boško Kostić that „Ljotić appeared before the Germans, the occupiers as an unknown man" (Boško N. Kostić, Za istoriju naših dana: Odlomci iz zapisa za vreme okupacije (Beograd: Nova iskra, 2011), 10) was certainly not true: mayby not every newly arrived German apparatchik knew who he was, but the very fact that only the Zbor was granted the permission to continue operating proves enough that Ljotić was very well known to the heads of the German occupation apparatus.

${ }^{38}$ Cf. Ferdo Čulinović, Okupatorska podjela Jugoslavije (Beograd: Vojnoizdavački centar, 1970), 49. In the political sense of the word. However, the former Yugoslav territory was still treated in many documents as a whole.

${ }^{39}$ M. Bojić, op. cit., 158. The fact is the Zbor realistically turned to operating only within the Serbian 
Ljotić, unlike his cousin premiere Milan Nedić, ${ }^{40}$ never renounced Yugoslavia in public. $^{41}$ In that way by staying loyal to King Peter II Ljotić faced smaller contradiction than Nedić who had renounced Yugoslavia, but not loyalty to its king. However, the problem was that king was in exile in a country considered allied, but at war with Germany and leading its own selfish policy. Loyally supporting the policy of Milan Nedić during WWII, ${ }^{42}$ the Zbor espoused Greater Serbia that would comprize both Serbia and the Sandžak of Novi Pazar, Montenegro and Eastern Bosnia. ${ }^{43}$ Ljotić's Yugoslavism would remain hidden throughout the three years of occupation and would make itself manifest in public only in late 1944 and early 1945, after Ljotić, the Zbor and the Germans had left Serbia. At that point it was certainly a function of creating a unified anti-communist front, but the sources give no hint that in Ljotić's case, it was not heartfelt. ${ }^{44}$ In any case, leaving the observation box ${ }^{45}$ and entering the arena where the real political fight was going on, demanded of him certain degree of dissembling.

framework under new circumstances, but Stefanović is subverting the truth when he says the movement became „Greater-Serbian“ overnight (Cf. M. Stefanović, op. cit., 122-123.) Branko Petranović laconically claims the same (Branko Petranović, Srbija u Drugom svetskom ratu 19391945 (Beograd: Vojnoizdavački i novinski centar, 1992), 391). The truth is that prominent member of the Zbor leadership, enegeneer Milosav Vasiljević, penned a study about creation of Greater Serbia in 1943 (AJ, 110-765; M. Stefanović, op. cit., 230-231), but there is nothing to suggest Ljotić lent support to that plan.

${ }^{40}$ M. Bojić, op. cit., 211-212. Nedić attacked Yugoslavism mostly indirectly, but clearly, above all by fanatically stressing only Serbdom (Cf. M. Bojić, op. cit., 211-212; M. Borković, Kontrarevolucija, I, 258; Milan Đ. Nedić, Desna Srbija: Moja reč Srbima 1941-1944: Izabrani ratni govori (Beograd: Slobodna knjiga, 1996), esp. 21, 44, 48, 52, 53, 59, 63; F. Čulinović, op. cit., 446, 461). The claim by Stanislav Krakov, Milan Nedić's nephew, that his uncle „struggling in public for Serbia wished to preserve loyaly, as much as possible, traditions of the Kingdom of Yugoslavia“ are not substantiated by any source, whereas there many proves to the contrary (Cf. Stanislav Krakov, General Milan Nedić, II: Prepuna čaša čemera (Beograd: Nova iskra, 2012), 261). According to some information, Ljotić condamned (although not in public) people who denigrated Yugoslavia during the occupation (IAB, BdS, I, reg. br. 35; BdS, J 423).

${ }^{41}$ This made it possible for several hundert pro-Yugoslav Croats and Slovenes to fight within the framework of the Serbian Volunteer Corps that stood under Zbor's influence. Most of them had to flee their homelands where they had been persecuted for their pro-Yugoslav sentiments. They understood the excessive stress on Serbiandom in the occupied Serbia as the necessary evil caused by the prevailing circumstances and it seems they had no problem with it (Cf. M. Bojić, op. cit., 213; H. Magazinović, op. cit., 224; Bojan B. Dimitrijević, Vojska Nedićeve Srbije: Oružane snage srpske vlade 1941-1945 (Beograd: ISI, 2011), 82-83).

${ }^{42}$ B. Kostić, op. cit., 97.

${ }^{43}$ M. Bojić, op. cit., 159.

${ }^{44}$ H. Magazinović, op. cit., 217-218; M. Stefanović, op. cit., 303-326. Certain disilusionment with Yugoslavism can be noticed in Ljotić's articles from 1930s, but it could not be understood as renaunciation. It can rather be said that he felt that the Yugoslav community, that he still perceived as the community of fate, should be reorganized on different basis. At the same time, he did not approve of the reorganization ushered by the Cvetković-Maček agreement, because he deemed it was founded on rotten principles and dishonesty. (D. Ljotić, SD, VIII, 124-125, 176, 208, 211; Ibid., XII, 71.) In a memo from spring 1944 Ljotić criticized the Germans for breaking up Yugoslavia. In his opinion, this was also to their own detriment, since Yugoslavia could have been a stability factor and a damm against communism. (M. Bojić, op. cit., 160.)

${ }^{45}$ Although he had been minister for several months in 1931 he could not take part in real deci- 
What at first glance seemed as strengtehning of the Zbor's position was the fact that Ljotic became a person close to powers-that-be. ${ }^{46}$ He was not only given free rain by the Germans, but was invited by Milan Aćimović, who had started putting up the Council of Commissars (the collaborationist administration's excuse for government), to take part in it. Ljotić declined, adducing unpopularity of his movement with the masses, claiming it would be detrimental to the esteem enjoyed by the Council of Commissars. ${ }^{47}$ In stead of that, he delegated two of his henchmen. In that way the Zbor became one of the „ruling parties ${ }^{648}$ and the only one that remained formally organized. ${ }^{49}$ Since joining the government did not include only the two members of the Council of Commissaries but also numerous Zbor members who entered the state apparatus, as well as the armed detachments, the movement had to contend with human weaknes of its members. Ljotić probably did not know of some of malfeasances the Zbor members commited in office, and he chose to turn the blind eye on others. ${ }^{50}$

sion-making (that remained king's preserve). His other political experiences have been gathered at provincial and grass-root levels. His activities in 1930s were rather those of a propagandist and ideologue than of a practical politician wielding real influence outside of his narrow circle of disciples.

${ }^{46}$ During 1931 Ljotic held office of a minister, but at that time he joined the government at king Alexander's behest, without support of any political party or interest group. Because of that he could leave the government smoothily when king refused his draft of the constitution. (D. Ljotić, $S D$, XI, 61-77; AS, BIA, II/69; M. Stefanović, op. cit., 20-21; M. Bojić, op. cit., 19). At the begining of the German occupation many ordinary members of the Zbor believed they realy had become ,the authorities“. Obrad Zalad wrote to Ljotić in his letter of June 18, 1941: „Many members of the Zbor, our comrades, are convinced that the Zbor commands the relative majority of the state power, and many that it at least has a say in all state affairs of which the persent commissars are in charge..." He complained the police were still persecuting the Zbor, especially the Administration of the City of Belgrade (AS BIA, II/72).

${ }^{47}$ M. Borković, Kontrarevolucija, I, 28-29; R. Parežanin, op. cit., 321; M. Stefanović, op. cit., 114-116; H. Magazinović, op. cit., 163; B. Kostić, op. cit., 22; Kosta Nikolić, Strah i nada u Srbiji 1941-1944: Svakodnevni život pod okupacijom (Beograd: Zavod za udžbenike i nastavna sredstva, 2002), 234. Ljotić's opinion was also shared by the chief of the Gestapo, Karl Kraus. According to Kostić, Ljotić resisted the pressure of the chief of the Military Administration, Dr. Harald Turner, to become minister of justice (B. Kostić, op. cit., 20-21; R. Parežanin, 320321). According to German sources, it seems at first Ljotić had agreed to become the commissary of the Ministry of Justice, but eventually changed his mind. (M. Borković, Kontrarevoluci$j a, \mathrm{I}, 33)$. With the lapse of time the standing of the Zbor in the eyes of the people did not improve - on the contrary (IAB, BdS, O 39).

${ }^{48}$ The word „party“ was used conditionally: political parties were not allowed under occupation, and the Zbor understood itself always as a „movement“" and not as a political party like the others.

49 Aaccording to Stanislav Krakov, some prominent members of the Zbor (Dr. Stevan Ivanić, Engeneer Milosav Vasiljević, Raša Arsenijević) claimed the Council of Commissaries was just temporary and that a Ljotić government would follow (S. Krakov, op. cit., II, 282). If this was true, they had been giving vent to their own wishes, not Ljotić's. There is information that Ljotić was left by some of his old adherents for collaborating with the occupiers, but in turn he gained some new, especially from among the refugees (AS, BIA, II/69).

50 Weaknesses were particularly manifest among the Zbor members in the Serbian Vounteer Command i. e. Serbian Volunteer Corps (since January 1943) (SDK), where cases of arrogance, undisciplin and uncomradely relations toward fellow-soldiers who were not members of the Zbor were registered. There were also accusations of pillaging (AS, BIA, II/73; IAB, BdS, 
This spoiled further the image of the Zbor members with the people (with whom they had been unopular as fascists and fift-colummnists already before the war) ${ }^{51}$ and indirectly of Ljotić himself.

For Ljotić joining the Council of Commissaries by the Zbor members was an attempt to help the people through collaboration in accordance with the international laws of war. ${ }^{52}$ Although formaly outside of the government, Ljotic was active ideologically and propagandistically in public. Apart from that, he was very influential behind the scene too, but the sources do not allow us to determin to what degree he actually managed to influence decisions of the Council of the Commissaries, the Nedić government (since September 1941) or the German authorities. When the uprising in Serbia started in summer 1941 he adressed the people on several occasions, calling on them to preserve peace and not to serve foreign (British, Soviet) interests. ${ }^{53} \mathrm{He}$ also appealed several times to German authorities to put an end to persecution and killing of the Serbian poplation in the Independent State of Croatia (NDH). It is interesting that his henchmen mention, apart from several intercessions for the Jews, a memo he sent to Hitler protesting persecution and murders of the Jews in Serbia. Allegedly the memo reached only the Reich's foreign minister, Joachim von Ribbentrop, who could not summon courage to show it to the Fuehrer, but who admonished Ljotic. ${ }^{54}$

J423; M. Bojić, op. cit., 226-228; M. Borković, Kontrarevolucija, I, 373-374.) As for the behaviour of the SDK on occasion of the notorious mass shooting of high-school students in Kragujevac on October 21, 1941, it seems no compromising information reached Ljotić. (M. Bojić, op. cit., 179-181.) Cf. Zbor's version of the event in R. Parežanin, op. cit., 509-514; M. Propadović, op. cit., 189-207. For the communist version cf. M. Stefanović, op. cit., 157-158. The best and all-encompassing survey of the tragedy is to be found in Staniša Brkić, Ime i broj: Kragujevačka tragedija 1941 (Kragujevac: Spomen-park Kragujevački oktobar, 2007). There are conflicting versions on the behaviour of the Zbor volunteers on that occasion. According to the communist one, they aided the Germans to commit the crime, and according to the Zbor's version, they were trying to save inocent civilians. (S. Brkić, op. cit., 51-57; B. Dimitrijević, op. cit., 96; Milan Borković, Milan Nedić (Zagreb: Centar za informacije i publicitet, 1985), 59; B. Kostić, op. cit., 56-57; Ljubinka Škodrić, Ministarstvo prosvete i vera u Srbiji 1941-1944: Sudbina institucije pod okupacijom (Beograd: Arhiv Srbije, 2009), 263; Borivoje M. Karapandžić, Građanski rat u Srbiji 1941-1945 (Klivelend (sic), Valjevo: Novo videlo, 2010), 95-98). Furthermore, there was the opinion that Ljotic had surrounded himself with bad people who made careers and lined their pockets under his aegis (AS, BIA, II/69). The prominent leftwing peasant politician, the Zbor-unfriendly Dragoljub Jovanović claimed they had pretended fanaticism already before the war in order to make people believe them, but were in fact either stupid wheeler-dealers, or shrewd crooks. According to him, Ljotić deceived himself, and they deceived him (Dragoljub Jovanović, Ljudi, ljudi...: Medaljoni 46 umrlih savremenika (Beograd: Autorovo izdanje, 1975), 156).

${ }^{51}$ Such image was broadcated by their political enemies headed by communists before the war, and during the war also by Draža Mihailović's chetniks who were on bad terms with the Zbordominated SDK in Serbia (but not elsewhere).

${ }^{52}$ Not even his worst political enemies tried to ascribe Ljotić's collaboration to his greed, since his personal modesty, long fasts and shaby clothes were proverbial. (M. Bojić, op. cit., 20.)

${ }^{53}$ D. Ljotić, $S D, X, 39-40,91,94,112 ;$ Ibid., XII, 114, 121.

${ }^{54}$ R. Parežanin, op. cit., 505-507. There is another version according to which Ljotić asked of the chief of the Military Administration Haralda Turnera, at first oraly and then in writing, to stop the persecution of the Jews. (B. Kostić, op. cit., 62.) 
At first glance this claim, confirmed by several witnesses, seems unbelievable. Why would a man who fought with his pen so vehemently against the Jews stand up in their defense? Ljotić's apologists readily quote one of his articles in which he encouraged breaking Jewish plans, but not their heads and shop-windows. ${ }^{55}$ His enemies will dismiss this as hollow words. However, the memoirs of Dr. Dragoljub Jovanović, who was certainly no political sympathiser of Ljotić's, but was incarcerated with him for a while during the inter-war period, tell us about how Ljotic threw bred to the isolated and poorly nurished communists - his worst political enemies! This can probably be explained by his deep Christian convictions. ${ }^{56}$ Because of that, it cannot be excluded that maybe he realy did send the memo to the Fuehrer wishing to end the persecution of the Jews. Even if he did, it had no effect, but it testifies to his complex caracter. On the other hand, there is nothing in the sources that would suggest that Ljotic realised how much he himself had contributed to creation of the antiSemitic environment or that he ever repented it. ${ }^{57}$ On the contrary: until the end of the war he remained true to his explanation that the origines of WWII were the Jewish desire to gain mastery over the whole world.

During the uprising in Serbia that was spreading fast, the main enemy could not be the numerically weak and persecuted Jews (and their alleged allies, the Free Masons), but communists. ${ }^{58}$ While they had been only one of the evils he had fought during the inter-war period, now they became the enemy number one, to whose destruction he devoted the remaining years of his life. To that goal he was willing to sacrifice even some of his ideals and even to act against his better convictions. ${ }^{59}$

At the same time, in keeping with his complex personality and deep Christian and national convictions, he was not one of the dumb anticommunists who believed communism could and should be destroyed only by brutal force. He realized that communism fed on poverty and suffering of broad masses (that were excecer-

${ }^{55}$ D. Ljotić, $S D$, XII, 56

${ }^{56}$ D. Jovanović, op. cit., 159. The chief of the Gestapo and the Security Service in Belgrade 1941/42, colonel Wilhelm Fuchs, claimed in a report that Ljotić was not energetic enough to implement the necessary measures for nationalization and for turning the tide in Serbia, as well as that he was too sentimental toward his former enemies [my italiscs - Z. J.] (AS, BIA, II/69).

${ }^{57}$ Ljotić's paper the Naša borba wrote consistently about contemporary and recent events in antiSemitic vein (Milan Koljanin, „Antisemitski stereotipi i propaganda u Srbiji 1941-1942“, Istorija 20. veka, 1, (2003), 99-104). Members of the Zbor denounced and arrsted hidden Jews and there were also demands that these be treated even more seve: Muzej žrtava genoida, 2012. (2nd expanded ed.)), 217-218.) Intelligence service of the Zbor also informed on the Jews. (Ibid., 116-117.) There are no available documents that suggest that Ljotic directly encouraged this, but also none that he did anything to prevent it.

${ }^{58}$ To be sure, Ljotic also supported the propaganda platitude that the partisans were led by the Jews. (D. Ljotić, $S D, \mathrm{X}, 58,104$.) Unlike Ljotić, together with the Jews, Nedić also stressed the Croats.

${ }^{59}$ This meant above all, accepting armed struggle. His participation in WWI had been preceded by his anti-militarist, Tolstoyan phase, but it seems his orthodox Christianity had been deffinitively fortified already before WWI. It did not prevent him from doing his military duty (AS, BIA, II/69). 
bated by many measures decreed by German authorities that Ljotić criticized) ${ }^{60}$, as well as that there were many noble idealsts among communist fighters too, who had been led astray by nice-sounding but false slogans. ${ }^{61}$ Because of that in 1942 he initiated the foundation of the Institute for Compulsory Education of the Young in Smederevska Palanka. ${ }^{62}$ Although his enemies claim it was a concentration camp, ${ }^{63}$ most of the facts point to the contrary. To be sure, freedom was limited, there was manual labor and hard life, and sometimes even corporal punishmets too. However, many of those limitations applied to normal schools too. ${ }^{64}$ On the other hand, in no concentration camp were regular visits by family members allowed, nor temporary leaves, passes, visits to other towns for sports and cultural events, medical treat-

${ }^{60} \mathrm{IAB}, \mathrm{BdS}, \mathrm{I}$, reg. br. 35.

${ }^{61}$ That Ljotic really perceived the Institute for Compulsory Education of the Young in Smederevska Palanka as ,the isle of salvation“ and not as ,,a penitentiary“ (cf. infra), is shown by his intercession for high-school graduates Milan Bratić and Miroslav Stanković who had collected money for the Communist Party of Yugoslavia. Ljotić asked for them to be sent to the Institute and not to a concentration camp, since they had come from good families and their guilt had been comparatively negligable (IAB, BdS, I, reg. br. 35).

62 This Institute has remained one of the most disputed points ever since the times of occupation, which spawned copious and mutualy conflicting literature (Cf. B. Kostić, op. cit., 89-94; M. Stefanović, op. cit., 197-210; Lj. Škodrić, Ministarstvo, 224-229; M. Bojić, op. cit., 235-246; Miloš Krstić, Nepokorena mladost. Koncentracioni logor u Smederevskoj Palanci 1942-1944 (Beograd: Vuk Karadžić, 1981); Maja Nikolova, Zavod za prinudno vaspitanje omladine $u$ Smederevskoj Palanci 1942-1944 (Beograd: Pedagoški muzej, 2010); Branislav A. Žorž, Zavod u Smederevskoj Palanci: Ostrvo spasa ili robijašnica (Beograd: Novo videlo, 2006); Marko Pivac, Koraci u noći (s. 1.: Novo videlo, [2002.]), 3-7, 69-79, 225-259; Milan Borković, SKOJ i omladinski pokret u Srbiji 1941-1944 (Beograd: Rad, 1970), 219-229; AS, BIA, II/50; M. Propadović, op. cit., 171-188; Slobodan Đ. Kerkez, Obrazovno-kulturne prilike u Nedićevoj Srbiji (Niš: Centar za balkanske studije, 2008), 114-115, 123). Most authors mention Ljotić as the initiator of the Institute. The fact that most tutors were members of the Zbor or clse to it, as well as that Ljotic closely observed the work done at the Institute, visited it several times and held lectures there, seem to confirm that he was its originator.

${ }^{63}$ Thus the State Commission for Establishing the Crimes of the Occupiers and their Abettors claims the Institute was a branch of the Banjica concentration camp (AJ, 110-768), although documents depict it as completely independent institution.

${ }^{64}$ Thus mandatory labor was organized for students of middle and high schools (Zoran Janjetović, „U skladu s nastalom potrebom... “ Prinudni rad u okupiranoj Srbiji 1941-1944 (Beograd: INIS, 2012), 205-206; Dragoslav Vojčić, „Školstvo u okupiranoj Srbiji tokom Drugog svetskog rata“, Nastava i vaspitanje, XXII, 2, (1973), 240-241; S. Kerkez, op. cit., 122.) High school students were exposed to political indoctrination. Parents also had to attend anti-communist lectures and had to guarantee for political loyalty of their children. Teachers kept card indexes of their pupils who were divided in three groups, depending on their political reliability. (AJ, 110806; Miodrag Simić, „Škole u Beogradu za vreme okupacije od 1941. do 1944. godine“, Godišnjak grada Beograda, XXI, (1971), 75-118; Vojčić, op. cit., 235-241. Furthermore, not only the inmates of the Institute but all inhabitants of occupied Serbia had to suffer hard living conditions and lack of food, fire-materials, clothes and shoes. (M. Borković, Kontrarevolucija, I, 251-252, 261, 390-393; Ibid., II, 111-113, 122-123, 133; Idem, Milan Nedić, 92, 140, 193; Nataša Milićević, Dušan Nikodijević (eds.), Svakodnevni život pod okupacijom: Iskustvo jednog Beograđanina 1941-1944 (Beograd: INIS, 2011), passim; Karl-Heinz Schlarp, Wirtschaft und Besatzung in Serbien 1941-1944: Ein Beitrag zur nationalsozialistischen Wirtschaftspolitik in Südosteuropa (Stuttgart: Franz Steiner Verlag, 1986), 302-337; Dragan Aleksić, Privreda Srbije u Drugom svetskom ratu (Beograd: INIS, 2002), 175-180, 207-213.) 
ments outside of camps and lectures by prominent public personages and respected scholars - including University professors. Furthermore, if the Institute had been a concentration camp, some former charges would not return on their own free will after having been discharged, nor would some parents willingly send their children to it - even if it was only to save them from going to real concentration camps. The inmates were indeed, like all pupils in Serbia, exposed to ideological pressure of their tutors, but unlike other pupils in Serbia, they were able to learn about much broader spectre of philosophical and political ideas. Ljotić's idea and that of his collaborators ${ }^{65}$ was to return the ,youth gone astray to the right national path" through convincing and proving.

The first imediate task that imposed itself in summer 1941 was quelling the partisan and chetnik uprising. Realizing thet the Council of Commissaries was not able to put down the uprising, Ljotić decided to topple it and to create a government that would enjoy more authority. He wrote resignations for his representativs on the Council, causing thus the resignation of the whole Council. He aided his relative, former General, Milan Nedić, who as patriot had enjoyed considerable esteem with the people, to become new prime minister with broader authority. He himself declined again to become minister, but offered several of his adherents. ${ }^{66}$ Again he excused himself with his and his movement's unpopularity with the people who had perceived them as fifth-colummnists already before the war. ${ }^{67}$ Through the duration of Milana Nedić's government (that resigned and was reconstructed several times) Ljotić remained outside of it, but very close to it. ${ }^{68}$ Maybe the rasons

${ }^{65}$ The head master of the Institute, Milovan Popović, was ideologically close to the Zbor but not its member, whereas head of the female part of the institution, his wife Dr. Dragojla Popović, was.

${ }^{66}$ IAB, BdS, I, reg. br. 35; M. Borković, Kontrarevolucija, I, 80-104; M. Propadović, op. cit., 111-112; R. Parežanin, op. cit., 334-335; H. Magazinović, op. cit., 177-179; M. Bojić, op. cit., 173; B. Kostić, op. cit., 42-46; M. Stefanović, op. cit., 133-137. According to Borković the main negotiations about forming the government were conducted between Nedić and German officials, whereas Milan Aćimović and Dimitrije Ljotić were only go-betweens. (M. Borković, Kontrarevolucija, I, 99.) There is also a version according to which it was the Germans who would not allow Ljotić to join the government because he had been a religious fanatic. According to the same source, Nedić himself kept him away from power (although he used him), whereas the powerful manager (administrative-cum-police chief) of the City of Belgrade, Dragi Jovanović, intrigued against him among the Germans (AS, BIA, II/69). This version seems to be confirmd by Aleksandar Cincar-Marković's after-war statement that Ljotić did not want to join the cabinet due to his animosity toward Nedić (and Milan Aćimović). (F. Čulinović, op. cit., 429). His enmity for Aćimović is documented in other sources too, but the claim about his animosity toward Nedić does not sound plausible. It is controverted by a number of sources testifying to their cooperation, if not always to identity of opinions.

${ }^{67}$ IAB, BdS, I, reg. br. 35. According to the report by Branislav Maksimović to Nedić of March 3, 1942, Ljotić's propaganda was demoralizing the people because he was perceived ,as the branchoffice of the German Reich“. (Vojni arhiv, Nedićeva arhiva (VA NA), k. 3, f. 2, d. 13). Other members of the Zbor were also aware of their own unpopularity (AS, BIA, II/73; BIA, I/146).

${ }^{68}$ According to a rumor, general of the SS-police, Meyszner, offered Ljotić to take over power with his volunteers in early 1942, but Ljotić declined - according to Mihajlo Olćan, because of his excessive moral standards and out of regard for Nedić (IAB, I, reg. br. 35). Considering 
were those he had adduced, and maybe he was simply afraid of responsibility. The latter possibility is quite probable in the light of Milan Nedić's government's impotence: why taking over responsibility for things he could hardly change? Nevertheless, he always believed it was worth collaborating with the Germans for the benefit of the people. ${ }^{69}$ This view was, with many oscilations caused by numerous disapointments, shared by Nedic too, and in his public speeches and articles Ljotić staunchly supported him throughout the war. ${ }^{70}$ Their personal relations were certainly not ideal - especially since other groups also competed for predominance in the government, ${ }^{71}$ as well as Nedić himself did - but scanty and contradictory sources prevent us from knowing more about it. ${ }^{72}$ Ljotić was eminence grise certainly to be reckoned with, ${ }^{73}$ but it is an open question how far his actual influence on the government and its decisions reached.

Meyszner's opinion of the SDK as a possible security threat and the measures he was undertaking against it exactly at that time, this version does not sound convincing.

${ }^{69}$ M. Propadović, op. cit., 124.

${ }^{70}$ D. Ljotić, $S D$, X, 52, 158-159, 163-164, 175-176, 178; Ibid., XII, 182-187; H. Magazinović, op. cit., 214.

${ }^{71}$ These groups also strove to set Nedić and Ljotić by the ears (H. Magazinović, op. cit., 214). On the struggle of various groups (former members of the Yugoslav Radical Union (JRZ), professional army officers etc.) against the influence of the Zbor cf. Odnos političkog pokreta „Zbor" a preko ovog i SDK prema četništvu Draže Mihailovića, [by Milisav M. Grujić, 1949.] (AS, BIA, I/32). Parežanin is embellishing the truth (to say the least) when he writes Nedić and Ljotić were in agreement on everything. (R. Parežanin, op. cit., 342-343.)

72 There are reports from April and May 1942. about tensions between Ljotić and Nedić and about struggle of the Zbor members to gain more important ministries in the government. Borković speaks about Ljotić blackmailing Nedić (IAB, BdS, I, reg. br. 35; M. Borković, Kontrarevolucija, I, 376-377). Ljubinka Škodrić writes Nedić tried to diminish Ljotić's influence and that he and his government feared the influence Ljotić had with the Germans (Lj. Škodrić, Ministarstvo, 220). On occasion of the government's resignation in late summer 1942, Nedić complained to the chief of the Military Administration Turner that members of the Zbor had been undermining his authority and proposed Ljotić for the new prime minister. Turner declined this because he believed Ljotić was a visionary and not fit for a statesman (Idem, „Odnos nemačkog okupatora prema domaćim saradnicima u Srbiji 1941-1944“, Oslobođenje Beograda 1944: Zbornik radova (Beograd: INIS, 2010), 92). The alleged Ljotić's attempt at the coup d'etat (caused by strengthening of Nedić's power) in late 1943 mentioned by some authors and recorded in some informants' reports (AS, BIA, II/76; BIA, II/72; M. Borković, Kontrarevolucija, II, 195; Idem, M. Nedić, 250; Lj. Škodrić, Ministarstvo, 221; Vasa Kazimirović, Srbija i Jugoslavija, IV (Kragujevac: Centar-film, Prizma), 1995), 1146) was not very likely because the armed forces under his influence were not very numerous and were hated by the populace to boot. Furthermore, the Germans would never have allowed it, i. e. Ljotić had much better chances of deposing the government by political means and with the aid of German authorities, than by a military putsch without their approval. According to German sources, Nedić and Ljotić parted company in October 1944 after quarreling over withdrawal routes from Serbia. Allegedly, during the argument, they accused each other of betraying Serbian national cause. (M. Borković, Kontrarevolucija, II, 348).

${ }^{73}$ Having his representatives in both the Council of Commissaries and in the Government of National Salvation, Ljotić could control their stability to a large degree. Thus a government crisis set in as two of his ministers announced their resignations in August and September 1942 (M. Borković, Kontrarevolucija, I, 360-361). 
Despite the claims he was uncrowned king of the occupied Serbia, ${ }^{74}$ there are hints that suggest that his influence was not too large. ${ }^{75}$ First of all, practical competences of the Serbian government were extremely limited. Apart from that, the number of Zbor members in highest offices (ministers, county chiefs) was small. It was only in 1943 that the number of county and district chiefs from their ranks was increased. ${ }^{76}$ According to Hrvoje Magazinović, some 100 Zbor members were shot in the infamous German mass retaliation in Kraljevo in $1941 .{ }^{77}$ The plan for reorganizing social and political system in Serbia submited by Nedić to the German authorities in early 1943 was mostly not marked by the Zbor social ideas, ${ }^{78}$ and was in the oppinion of the occupation powers-that-be rather a copy of fascist and nazi social order. ${ }^{79}$ Cultural policy the only field in which Serbia had some kind of autonomy - was directed by

${ }^{74}$ Dragi Jovanović, chief of the Administration of the City of Belgrade and chief of the State Security Service claimed during his interrogation after the war, that Ljotic controlled two thirds of county and district chiefs and that Nedić stood under tutelage of Ljotić and former Austrian consul Robert Kronholz. (M. Borković, Kontrarevolucija, I, 166.) This seems as more than an exagguration and the statement was probably made in order to shift the bulk of his own responsibility to Ljotić, who had already been dead by that time. The fact that the German intelligence services have „regularly hearkened Ljotić's voice“ (Ibid., 167) cannot be a proof of his exceptional power: German intelligence officers had their eyes on a large number of more or less prominent persons. (Cf. holding BdS in Istorijski arhiv Beograda). Conversly, stalking could be understood as the proof of the tailed person's weak influence and a sign of distrust on part of the security services following him.

${ }^{75}$ Ljotić did not belong to the inner circle of Nedić's advisors, whereas some of Zbor's oponents did. (Lj. Škodrić, Ministarstvo, 220; M. Bojić, op. cit., 210-211). There is also the version according to which it was Ljotić who had ,pushed“"Nedić to the far-right. (IAB, BdS, I, reg. br. 35).

${ }^{76}$ Elaborat: Odnos političkog pokreta „Zbor“ a preko ovog i SDK prema četništvu Draže Mihailovića, [by Milisav M. Grujić, 1949.] (AS, BIA, I/32).

${ }^{77}$ H. Magazinović, op. cit., 188.

${ }^{78}$ Ljotić and the Zbor espoused social order based on professional estates that would elect representatives to the National Assembly. The state would be headed by king and the government, but their mutual relaiton was left vague. (Cf. D. Ljotić, SD, IV, 62, 85; Ibid., VI, 38, 70, 106, 110-112; Ibid., IX, 152; Ibid., XI, 123-124; M. Bojić, op. cit., 39-44.)

${ }^{79}$ Nedić's draft foresaw a Serbian peasants' state, without king, with large role of cooperatives and an advisory Parliament, county and district councils whose members would be appointed, not elected. (Cf. M. Borković, Kontrarevolucija, II, 33-40. Cf the complete text in: Karl Hnilicka, Das Ende auf dem Balkan 1944/45 (Göttingen, Zürich, Frankfurt: Musterschmidt Verlag, [1970]), 239-252.) The Greman authorities judged the draft to be a copy of the fascist and nazi systems, and the commanding general in Serbia, Paul Bader, even suspected that Italy had been behind the whole scheme. After consulting relevant German offices, the demand for reorganization of Serbia was shelved due to Hitler's and Bader's oposition. (M. Borković, Kontrarevolucija, II, 40-44.) In fact there was no similarity with the Italian system, although the vocabulary of the memo was atuned to nazi readers. (Cf. Benito Mussolini, Fascismo, 15-17, 123-144, in: www.tereccani.it/enciclopedia/fascismo_(Enciclopedia italiana), accessed May 7, 2014; Danilo Gregorić, Italijanski korporativizam: Istorijat, doktrina i praksa (Beograd: Štamparija Đura Jakšić, 1940), (esp. 29-61); S. William Halperin, Mussolini and Italian Fascism (Princeton NJ: Anvil, 1964), 54-62, 122-124, 129-133160-161; P. Milza, S. Berstein, Storia del fascismo: Da Piazza San Sepolcro a Piazza Loreto (Milano: BUR, 1995), 325-335; Federiko Šabo, Italija (1918-1948) ([Beograd: Nolit, 1978]), 97-103). Fascism did not come into being as „export goods“ (B. Mussolini, op. cit., 122), and its corporate system was tailored for the Italian society that has been industrialized to a considerable degree. 
Zbor's renegades who had quit it long time before. ${ }^{80}$ Although the Serbian volunteer detachments have acquited themselves well in combat against the partisans, once the danger was over, the chief of the SS-Police in Setbia, general Meyszner, eyed them with suspicion and even disarmed some of them in 1942, whereas commander of the SDK Kosta Mučicki and several other officers were arrested in December $1941{ }^{81}$ Finally, some prominent members of the Zbor were subject to investigations by the Gestapo and the Special Police, ${ }^{82}$ and even Ljotic was interrogated and his apartment searched. ${ }^{83}$ On the other hand, the pelenipotentiary of the German Foreign Ministry, Felix Benzler, once said he „,could do nothing against Ljotić, he could do notihg with Ljotić, and he could do nothing without Ljotic" ${ }^{84}$ which would imply a far reaching influence of the Zbor's leader. It is certain that Ljotić, as excelent orator, could excercise the strongest influence in prsonal contacts with general Nedić and with German officials. ${ }^{85}$ It was probably thanks to his influence that a member of the Zbor, colonel Miloš Masalović (who had held the same office before the war when Nedić was Minister of the Army and the Navy) became chief of Nedić's cabinet, ${ }^{86}$ and probably influenced his boss in Ljotić's spirit.

Ljotic had undisputedly the strongest influence on the not very numerous members of his movement, and then on also not very numerous members of the Serbian volunteer detachments. These were founded in mid-September 1941 in accordance with the agreement between Nedić and Ljotić with the aim of puting down the uprising of the partisans and Draža Mihailović's chetniks. While the

${ }^{80}$ Minister of Education, Velibor Jonić, parted ways with the Zbor already in 1938. Although under occupation he formally made his peace with Ljotić, he remained his sworn enemy. (Lj. Škodrić, Ministarstvo, 220, 223.)

${ }^{81}$ Elaborat: Nešto o „Zboru“ i „Belim orlovima“, AS, BIA, I/32; B. Dimitrijević, op. cit., 266; M. Bojić, op. cit., 231-232; S. Krakov, op. cit., II, 434; R. Parežanin, op. cit., 466; K. Hnilicka, op. cit., 226-233. The SDK was not strengthened until 1944 because there was no need for it. The German authorities started eyeing it more favorably only in spring 1944 when Meyszner had been recalled and the military situation had become very unfavorable for the Germans (M. Borković, Kontrarevolucija, II, 289-290; B. Dimitrijević, op. cit., 299; M. Bojić, op. cit., 225-227). Mladen Stefanović's claim the Germans had always had unlimited confidence in the SDK is a propaganda legend (Cf. M. Stefanović, op. cit., 260). According to Kostić (the well documented) German mistrust of the SDK (especially of the commander of the SS-police, Meyszner) (K. Hnilicka, op. cit., 228-233, 235.) had its good rasons. According to him, Ljotić believed in ultimate German defeat and wanted to have strong ,nationalist forces" at his disposal once it happened. (B. Kostić, op. cit., 128-129.) It may be that this was a post-war apology.

${ }^{82}$ E. g. engeneer Milosav Vasiljević when he resigned as secretary of the Workers' Chamber in March 1942. (M. Bojić, op. cit., 216).

${ }^{83}$ This is claimed by Boško Kostić and Ratko Parežanin. (R. Parežanin, op. cit., 413; B. Kostić, op. cit., 67-68.) Kostić claims there are minutes of Ljotić's interrogations in archives. Unfortunately, he does not say in which archives. To the best of our knowledge, they have not surfaced so far - which does not exclude the possibility they will some day.

${ }^{84} \mathrm{IAB}, \mathrm{BdS}, \mathrm{I}$, reg. br. 35.

${ }^{85}$ Mihajlo Olćan claimed in April 1942, that Nedić had already fallen under the influence of the people from his entourage and was no longer under the influence of Ljotić, who had brought him to power. (IAB, BdS, O39).

${ }^{86}$ Among other things, Masalović was Ljotić's best man at the wedding. (B. Dimitrijević, op. cit., 374.) 
gendarmes were a regular police formation, volunteer detachments were meant to serve as auxiliary police - at first made up to a large extent of young members of the Zbor. ${ }^{87}$ Although the Serbian Volunteer Command (later on renamed Serbian Volunteer Corps) was founded on the initiative of the Zbor, it was soon expanded and filled with non-Zbor members. ${ }^{88}$ Nevertheless, the members of the Zbor had the predominant influence, whereas Ljotić excercised his by initiating the foundation of the Educational Service he supervised and directed. The task of the service was to shape politically the members of the detachments in the anti-communist way. As the end of the war neared and the chances of Soviet victory grew, Ljotić's articles and speaches directed at the members of the SDK became increasingly mystic and religiously inspired. ${ }^{89}$ One gets the impression that not being able to offer victory to his adherents in this world, he increasingly tended to promise them reward in abstract religious spheres. ${ }^{90}$

Ljotić's influence was the weakest with Draža Mihailović's chetniks, who, according to many estimates, enjoyed sympathies of the large majority of population in Serbia. ${ }^{91}$ They were formally insurgents, and thus de iure enemies of the collaborationist government, but it cooperated with them through many chanels, including their part that was not „legalized“ in late 1941. Although he condamned them in public, ${ }^{92}$ Ljotic tried to be one of the chanals of that cooperation, believing in the necessity of a common national front against the communists. However, his and the Zbor's image as „fascists“ and „fifth-

${ }^{87}$ The formation, although it acted as part of the government's armed forces, remained under ideological influence of the Zbor. (B. Dimitrijević, 270.) Ljotić (together with Meyszner) opposed Milan Nedić's attempt at incorporating part or the whole of the SDK into the Serbian State Guard in 1942. (AS, BIA, II/72; M. Borković, Kontrarevolucija, I, 300; B. Dimitrijević, op. cit., 270). Obviously Ljotić did not want to renounce „his“ armed formation that gave him much more weight on the political scene.

${ }^{88}$ According to the data given after the war by the SDK commander Mušicki, the SDK was made up of some $30 \%$ members of the Zbor in the begining, whereas later, with the rise in overal number of soldiers from 1500 to 5000, the share of the Zbor members fell to $10 \%$. (B. Dimitrijević, op. cit., 83). According to the post-war statement by former Zbor member Milisav M. Grujić, the percentage of the Zbor members was still $20 \%$ even after the increase of soldiers' number (AS, BIA, I/32).

${ }^{89}$ D. Ljotić, $S D, X, 195-202$.

${ }^{90}$ IAB, BdS, I, reg. br. 35; M. Bojić, op. cit., 229-230; B. Dimitrijević, op. cit., 303-306; R. Parežanin, op. cit., 467-470.

${ }^{91}$ According to Parežanin, Ljotić was also aware of it and believed in March 1942 that $90 \%$ of the people in Serbia favored Draža Mihailović. (R. Parežanin, op. cit., 418). Similar claims are to be found in other sources too. (cf. Mladen J. Žujović, Ratni dnevnik, II: Jugoslavija u Drugom svetskom ratu (Vrnjačka Banja: Interklima-grafika, 2004), 58; Aleksandar Vojnović, NDH u Beogradu (Zagreb: Naklada Pavičić, 1995), 345; K. Nikolić, op. cit., 205, 234, 237, 240). Due to the changeability of the wartime situation which always victimized the ,little man“, depending on time and place, there was also animosity toward Mihailović's chetniks (as well as against the partisans). (K. Nikolić, op. cit., 76, 178, 211, 223, 246, 251).

92 That condemnation was, however, never so severe as the one of the communists or the Jews. Since they were illegal, Ljotic could not help condamning them, but since they were nationalists (formaly Yugoslav ones at that) and anti-communists with whome he wanted to connect, he could not attack them so viciously as the communist insurgents. (D. Ljotić, $S D, \mathrm{X}, 54-60,123-126$ ). 
columnists" turned Mihailović's chetniks from cooperating with them in Serbia. Apart from that, struggle for primacy in certain places and areas, personal animosities of commanders etc. usually also prevented cooperation between the chetniks and the SDK (that can be viewed as the armed wing of the Zbor) ${ }^{93}$ Although Ljotić wantd to meet Draža Mihailović on several occasions, the latter always craftily avoided that - certainly not wanting to compromise himself with his patrons in London and striving to preserve his image as freedom fighter. It was only the looming defeat that spurred attempts at serious cooperation. ${ }^{94}$ On the other hand, outside of Serbia where general political conditions and the situation of the Serbian population were different, members of the Zbor were inducted into chetnik units and the Zbor and the SDK cooperated with the chetniks. ${ }^{95}$

Together with at least partial ideological affinity, faith in final German victory was the precondition of collaboration. During the first months of occupation as well as during the first months of the German campaign against the USSR it seemed that German victory was almost certain. During 1942, after the uprising in Serbia had been quenched and the German troops were still fighting comparativelly successfully at the Eastern Front, collaborationists could still believe it was worth while playing the German card. Although before Yugoslavia was plunged into war, he had written that Germany had been unwitting tool of the Jews, during the occupation Ljotic kept repeating the German propaganda platitude that the Third Reich was defending Europe from Asiastic bolshevik barbarity, expressing faith in German victory. He saw it as the sole salvation from communism. ${ }^{96}$ In other words: either Germany would win or Jewish communism. At the same time, according to Boško Kostić, he refused to send even a token force of his volunteers the the Eastern Front ${ }^{97}$ with the excuse the USSR was ally of the Serbian allies, so Serbian soldiers could not fight against it. Furthermore, he counted on traditional Serbian pro-Russian sentiments, he himself shared.

Another topos of the German propaganda Ljotić broadcasted in public was that Germany was no enemy of the Serbian people and that the Serbs

${ }_{93}^{93}$ B. Petranović, op. cit., 391-393.

${ }^{94}$ IAB, BdS, J 423; B. Kostić, op. cit., 101-106, 120-126, 145-160, 199-233; M. Bojić, op. cit., 174-206. The reasons were also to be found in Mihailović's ties with the Yugoslav government in exile and with the British, in oposition to cooperation with the Zbor on part of his adviser Dragiša Vasić and in the fact that the chetniks turned their insurgency against the members of the SDK and not against the Wehrmacht - which would lead to German reprisals against the people and consequently to unpopularity of the Yugoslav Army in the Fatherland.

${ }^{95}$ M. Bojić, op. cit., 253-260; B. Kostić, op. cit., 130-137.

${ }^{96} \mathrm{He}$ set this alternative already before the occupation. (D. Ljotić, SD, IX, 194; Ibid., X, 176, 191; Ibid., XII, 178). He believed apart from Germany, only Spain and Serbia (sic) could save the world from communism - if national forces were united. (IAB, BdS, I, reg. br. 35).

${ }^{97}$ M. Borković, Kontrarevolucija, I, 300; M. Stefanović, op. cit., 176; B. Kostić, op. cit., 66. It should be noted that among the Zbor volunteers there was willingnes to go to fight communism at the Eastern Front. Nedić and his ministesr oposed that (IAB, BdS, I, reg. br. 35; M. Borković, Kontrarevolucija, I, 160-161). Ljotić deemed that struggle could be led just as well in Serbia. 
should regain through wisdom the freedom they had lost through folly. ${ }^{98}$ This thesis had a core of truth, ${ }^{99}$ but faced with the reality on the spot, a common man found it hard to believe in it. Germany indeed wished no war with Yugoslavia and attacked it only when Yugoslavia turned out to be an unreliable insecurity factor in the Reich's rear. Although Hitler did want to punish the Serbs, at least in Serbia they could have awaited peacefully the end of the war, had there been no premature uprising. ${ }^{100}$ The uprising, in turn, led to brutal German reprisals. When large contributions in money and goods incumbent on Serbia, mandatory labor in mines and on building sites and persecution of the Serbian population outside of Serbia that the Germans rarely sought to alleviate, are added, it is clear that it was difficult for an ordinary Serbian citizen (who was exposed also to communist, chetnik and British propaganda) to believe that Germany was not an enemy of the Serbian people. Appeals to preserve law and order and not to heed calls of various insurgents probably met with more understanding, but were hard to implement as long as various armed bands were roaming the land. In any case, Ljotić joined in chorus of those spreading such ideas in the Serbian public. ${ }^{101}$

As the war progressed, the fate in German victory receded, but since it was punishable, no-one dared express his doubts in public. ${ }^{102}$ Not even Ljotić. However,

${ }^{98}$ D. Ljotić, SD, X, 39-40, 94, 112; Ibid., XII, 114, 121; M. Bojić, op. cit., 159-160, 209; M. Propadović, op. cit., 125. Approchement between the Serbs and the Germans that Ljotić tried to bring about, was assessed by Bojić as „doubly impossible task“. (M. Bojić, op. cit., 159.) On German propaganda cf. Kosta Nikolić, „Nemačka ratna propaganda u Srbiji 1941-1944“, Jugoslovenski istorijski časopis, 1, (1997).

${ }^{99}$ The fact is that Germany at first did not seek to attack Yugoslavia but rather to win her over for the Axis through a mix of diplomatic pressure and concessions. The attack occured only after the putsch of March 27, 1941 convinced Hitler that Yugoslavia was an unreliable partner. (Cf. Jakob B. Hoptner, Yugoslavia in Crisis 1934-1941 (New York: Columbia University Press, 1962); Dušan Lukač, Treći rajh i zemlje jugoistočne Evrope, II, 1937-1941 (Beograd: Vojnoizdavački centar, 1982), 456-478; Johann Wuescht, Jugoslawien und das Dritte Reich: Eine dokumentierte Geschichte deutsch-jugoslawischen Beziehungen von 1933 bis 1945 (Stuttgart: Seewald Verlag, 1969), 149-158, 303-305; Kosta Nikolić, Bojan B. Dimitrijević, Danilo Gregorić i 25. mart 1941 (Beograd: ISI, 2007), 84-129; David Irving, Hitler's War and The War Path (London: Focal Point, 2002), 368-369; Slobodan D. Milošević, Nemačko-italijanski odnosi na teritoriji okupirane Jugoslavije 1941-1943 (Beograd: ISI, 1991), 23-30). Between August 1939 and July 1940 Hitler had „offered“ Mussolini to attack Yugoslavia, but curbed such intentions afterwards (S. Milošević, op. cit., 16-23).

${ }^{100}$ The nazis did not exclude deffinitively a possibility of some kind of Serbian state after the war. (F. Čulinović, op. cit., 64, 70, 393.) On the contrary. Foreign minister Joachim von Ribbentrop wired already on May 3, 1941 to his penipotentiary in Belgrade, Benzler, that Hitler had intended to set up Serbia as an independent state. (Ibid., 396).

${ }^{101}$ More on the propaganda of the Nedić government in Olivera Milosavljević, Potisnuta istina. Kolaboracija u Srbiji 1941-1944 (Beograd: Helsinški odbor za ljudska prava u Srbiji, [2006.]); Milan B. Matić, Štampa u Srbiji u Drugom svetskom ratu 1941-1944 (Beograd: (Ph. D. mscr.), 1990), 1-236; M. Borković, Kontrarevolucija, II, 273-279.

${ }^{102}$ Göbbels himself spoke about victory in his last speach on occasion of Hitler's birthday on April 20, 1945 - at the time soldiers of the Red Army were already on the streets of Berlin. (Friedemann Bedürftig, Drittes Reich und Zweiter Weltkrieg: Das Lexikon (München, Zürich: Piper, 2004), 140.) 
an informant's report survives in which it was recorded that Ljotić had said alrady in March 1943 that Germany would lose the war. ${ }^{103}$ No special perspicuity was needed to see that: that opinion was gaining ground rapidly among all those who had any access to information. Ljotić never exprssed doubt in German victory in public, but between the liens one could read that his confidence was not so adamant as before. ${ }^{104}$ Otherwise, why would he put the German-victory-or-communism dilemma before the public? He partly made public his doubts only in early 1945 after retreat of Serbian collaborationist forces to Slovenia. He was still focused on fighting communism: if not leaning on Germany, than on the Western allies, for whome he, like Hitler, believed would soon fall out with the Soviet Union. ${ }^{105}$ This testifies to his ideological staunchness and at the same time, refutes agin accusations of proGerman sympathies, or of sympathies for National Socialism as such.

WWII brought Ljotic the ideologue and the politician into a new situation. He must have seen Yugoslavia's plunge into the war as failure of his endeavours. ${ }^{106}$ He found himself in the position of a Yugoslav patriot collaborating with the occupiers who had dismembered Yugoslavia and in a position of a combatant militating against the sole truly Yugoslav movement (i. e. the partisans) in the territory of the dismembered former state. Once entering collaboration with the Germans, he had to pretend he believed in their victory even after he had realized they could not win the war. For fighting communism he had to put up with malfeasances of some of his adherents in government offices, ${ }^{107}$ with undiscipline, excesses and some imoral acts of the volunteer detachments

${ }^{103}$ IAB, BdS, I, reg. br. 35. Boško Kostić also writes that Ljotić believed in the Third Reich's ultimate defeat and wanted Serbia to have as strong armed forces as possible for that moment in order to prevent communists from taking power. (B. Kostić, op. cit., 128-129.) From Kostić's writing it is not clear when Ljotić expressed this opinion: in 1943 or in 1944.

${ }^{104}$ Thus he wote on June 24, 1944 that the war would last for a long time and that it would not reach its peak by the end of that year. (D. Ljotić, $S D, X, 178$.) During that year he also wrote about tenacity of German resistence, claiming only Germany had been a bulwark against communism. (D. Ljotić, $S D$, X, 183-184, 191, 204).

${ }^{105}$ D. Ljotić, $S D, \mathrm{X}, 242-243$.

${ }^{106}$ He once wrote that if his Bilten had been published for six more months, there would have been no putsch of March 19411941 and Yugoslavia would not have ended up at war. (D. Ljotić, SD, X, 43-44; R. Parežanin, op. cit., 206.)

${ }^{107}$ When the Zbor member Mihajlo Olćan became minister of economy, he was inundated by demands by the members of the Zbor that were supported by the movement, to secure them jobs. They were carbon-copied and only the name of the candidate changed. There is a complaint from May 1942 that members of the Zbor thus employed in the Central Office for Wheat were lazy, incapable and prone to nepotism, whreas the chief of the Central Office for Chemical Products, a mermber of the Zbor, allegedly tolerated malpractice of his employees (AS, BIA, II/73). Ther were also complaints that Ljotić had sourounded himself with bad people who caused dissatisfaction among the members of the Zbor (this was claimed e. g. by Vladimir Ćelper on June 22, 1941) (AS, BIA, II/73. Cf. also Zbor Dimitrija V. Ljotića, 12.V 1952, AS, BIA, II/69), as wll as that the older members made careeres in Belgrade as managers, commissaries and well paid state officials, while the young members were bleeding on the battlefield (AS, BIA, II/72). Mihajlo Olćan was one of the prominent members of the Zbor who showed great hunger for power. (Cf. his letter to the General Plenipotentiary for the Economy in Serbia, Franz Neuhausen of April 2, 1942. (IAB, BdS, O 39.) Cf. also the already quoted statement by Dragoljub Jovanović about the people from Ljotic's entourage (D. Jovanović, 156). 
that stood under Zbor's influnce. ${ }^{108}$ He wanted to change the whole people, but could not influence enough many of the members of his own movement. He had to cooperate with a number of people he otherwise morally censured. During the last phase of the war he even had to count on possible collaboration with those against whome he had written and spoken for a decade: Western plutocrats $^{109}$ - about whome he believed the Jews stood behind them. Neverthless, he did not expect the ,sobering“" of the West before it started fighting the USSR. ${ }^{110}$ His situation was made even more difficult by suffering of the Serbian people during WWII and by his inability to lend them any meningful help. By wanting to help his people, he willingly accepted the stigma of a collaborationist, hiding his deepest convictions. However, due to his ideological miopia, his wish to help led him to become part of the problem, instead part of the solution: in Serbian society that had been so divided under occupation his exclusive anticommunism could not be a factor of peace and it led him into misunderstanding both the causes and the progress of the war. His blind anti-Semitism not only saduced him in de facto supporting injustice (that he probably did not wish in such monstruous form) toward his Jewish fellow-citizens, but prevented him from realizing the real meaning of WWII, regardless of the fact that he correctly interpreted and predicted some of its phases. ${ }^{111}$ Ljotic became the victim of the wartime circumstances, but mostly of himself: he could do nothing against Ljotića, he could do nothing with Ljotić and he also could do nothing without Ljotić. $^{112}$ Despite his undisputed intellectual capacities and education, he could not jump over his idological shadow.

${ }^{108}$ M. Borković, Kontrarevolucija, I, 373-374; M. Bojić, op. cit., 226-228; B. Dimitrijević, op. cit., 300; R. Parežanin, op. cit., 471-475. It should be kept in mind that the reports about the SDK, depending on who wrote them, were very biased. Members of the SDK and of the Zbor stressed how beloved volunteers had been among the people due to their struggle against communism and aiding the peasants with works in the field (VA NA, k. 24, f. 5, d. 36; AS, BIA, II/69), whereas their oponents from among the Serbian State Guard, the chetniks and the partisans depicted them in the worst possible light - as rabble, bullies and plunderers, more feard by the people than the Germans themselves (AJ, 110-765; VA NA, k. 1a, f. 2, d. 37; AS, BIA, I/146; BIA, II/69; Izveštaji i naredbe organizacije DM i organizacije Zbor za Okrug zaječarski 1943-1944. godina, III (Negotin: Istorijski arhiv Negotin, 2008), 84-85). Due to fight over influence with other military formations, small number of members of the SDK and of the Zbor, as well as due to the already existing bad press enjoyed by them, it is clear that reports detrimental to the SDK predominated. The members of the SDK are accused of various acts of violence, especially against the members of the Serbian State Guard. The fact that these reports stemmed from the rival camp, does not mean they had not been true in many cases, especially since there were also self-critical reports by officers of the SDK that prove that at least part of the accusations from other beliguerant parties was true (AS, BIA, II/69).

${ }^{109}$ H. Magazinović, op. cit., 228, 232.

${ }^{110}$ D. Ljotić, SD, X, 203-204; B. Kostić, op. cit., 188.

111 According to Ljotić's explanation from early 1945, WWII was a clash between nationalism and communism (D. Ljotić, $S D, \mathrm{X}, 202-205)$, i. e. it was fought so that Soveit dominance in Europe could supersede German one (D. Ljotić, SD, X, 224-238).

${ }^{112}$ His close collaborator, Mihajlo Olćan, described him as a great man who, as a politician, was not up to everyday events. According to him, Ljotić's strongest and at the same time weakest point was his relitgiosity (IAB, BdS, O39). In a way Ljotić himself confirmed this by saying 


\section{REFERENCES}

- Aleksić, Dragan. Privreda Srbije u Drugom svetskom ratu. Beograd: INIS, 2002.

- Bedürftig, Friedemann. Drittes Reich und Zweiter Weltkrieg: Das Lexikon. München, Zürich: Piper, 2004.

- Bojić, Mirko. Jugoslovenski narodni pokret „Zbor" 1935-1945: Jedan kritički prilaz. [Beograd]: Zakoni života-Svetlo istine, 1996.

- Borković, Milan. SKOJ i omladinski pokret u Srbiji 1941-1944. Beograd: Rad, 1970.

- Borković, Milan. Kontrarevolucija u Srbiji, Vol. I-II. Beograd: Sloboda, 1979.

- Borković, Milan. Milan Nedić. Zagreb: Centar za informacije i publicitet, 1985.

- Borozan, Đorđe. Velika Albanija: Porijeklo - ideje - praksa. Beograd: Vojnoistorijski institut Vojske Jugoslavije, 1995.

- Borozan Đorđe, and Ljubodrag Dimić (eds.). Jugoslovenska država i Albanci, vol. I-II. Beograd: Arhiv Jugoslavije, 1998-1999.

- Božović, Branislav. Stradanje Jevreja u okupiranom Beogradu 1941-1944. Beograd: Muzej žrtava genocida, 2012. (2nd expanded ed.).

- Brkić, Staniša. Ime i broj. Kragujevačka tragedija 1941. Kragujevac: Spomenpark Kragujevački oktobar, 2007.

- Čulinović, Ferdo. Okupatorska podjela Jugoslavije. Beograd: Vojnoizdavački centar, 1970.

- Dimitrijević, Bojan B. Vojska Nedićeve Srbije: Oružane snage srpske vlade 1941-1945. Beograd: ISI, 2011.

- Dragosavljević, Vasilije: „Ideološki uticaji evropskog fašizma na JNP Zbor (1934-1940)“. Istorijska tribina mladih saradnika. Urednik Zoran Janjetović, 93-111. Beograd: INIS, 2013.

- Gligorijević, Branislav. „Napad ljotićevaca na studente Tehničkog fakulteta u Beogradu, u oktobru 1940. i rasturanje Ljotićevog „Zbora“““. Istorijski glasnik, 16, (1963), 52-79.

- Gligorijević, Branislav. „Politički pokreti i grupe s nacionalsocijalističkom ideologijom i njihova fuzija u Ljotićevom „Zboru“““. Istorijski glasnik, 18, (1965), 35-82.

- Gligorijević, Branislav. „Osobenosti fašizma u Jugoslaviji dvadesetih godina“. Marksistička misao, 8, (1986), 32-44.

- Gregorić, Danilo. Italijanski korporativizam. Istorijat, doktrina i praksa. Beograd: Štamparija Đura Jakšić, 1940.

- Halperin, William S. Mussolini and Italian Fascism. Princeton NJ: Anvil Books, 1964.

that without his work „Drama savremenog čovečanstva“ (The Drama of the Contemporary Humanity) events in the world could not be understood (D. Ljotić, SD, VIII, 111.) and with an umodest statement untipical of him (written in a letter to the volunteers of the SDK), that God spoke through him (D. Ljotić, $S D, X, 195)$. 
- Hoptner, Jakob B. Yugoslavia in Crisis 1934-1941. New York, London: Columbia University Press, 1962.

- Hnilicka, Karl. Das Ende auf dem Balkan 1944/45. Göttingen, Zürich, Frankfurt: Musterschmidt Verlag, [1970].

- Iordachi, Constantin (ed.). Comparative Fascist Studies. New Perspectives. London, New York: Routledge, 2010.

- Irving, David. Hitler's War and The War Path. London: Focal Point, 2002.

- Izveštaji i naredbe organizacije DM i organizacije Zbor za Okrug zaječarski 1943-1944. godina, Vol. III. Negotin: Istorijski arhiv Negotin, 2008.

- Janjetović, Zoran. Deca careva, pastorčad kraljeva: Nacionalne manjine u Jugoslaviji 1918-1941. Beograd: INIS, 2005.

- Janjetović, Zoran. „U skladu s nastalom potrebom... “ Prinudni rad u okupiranoj Srbiji 1941-1944. Beograd: INIS, 2012.

- Jovanović, Dragoljub. Ljudi, ljudi... Medaljoni 46 umrlih savremenika. Beograd: izdanje autora, 1975.

- Jovanović, Žarko S.. Neostvareni ratni ciljevi Draže Mihailovića u Srbiji 1941-1945. Beograd: INIS, 2001.

- Karapandžić, Borivoje M. Građanski rat u Srbiji 1941-1945. Klivelend, Valjevo: Novo videlo, 2010.

- Kazimirović, Vasa. Srbija i Jugoslavija, IV. Kragujevac: Centar-film, Prizma, 1995.

- Kerkez, Slobodan Đ. Obrazovno-kulturne prilike u Nedićevoj Srbiji. Niš: Centar za balkanske studije, 2008.

- Koljanin, Milan. „Antisemitski stereotipi i propaganda u Srbiji 1941-1942.“ Istorija 20. veka, 2, (2003), 83-118.

- Kostić, Boško N. Za istoriju naših dana. Odlomci iz zapisa za vreme okupacije. Beograd: Nova iskra, 2011.

- Krakov, Stanislav. General Milan Nedić, Vol. II: Prepuna čaša čemera. Beograd: Nova iskra, 2012.

- Krstić, Miloš. Nepokorena mladost. Koncentracioni logor u Smederevskoj Palanci 1942-1944. Beograd: Vuk Karadžić, 1981.

- Kuljić, Todor. Fašizam. Sociološko-istorijska studija. Beograd: Nolit, 1987.

- Lacko, Mikloš. „Fašizam u istočnoj i srednjoj Evropi: Prilog opštoj definiciji fašizma“. Marksistička misao, 8, (1986), 120-136.

- Milza, P., S. Berstein, Storia del fascismo: Da Piazza San Sepolcro a Piazza Loreto. Milano: BUR, 1995.

- Larsen, Stein Ugelvik, Bernt Hagtvet, Jan Petter Myklebust, (eds.). Who Were the Fascists: Social Roots of European Fascism. Bergen, Oslo, Tromsø: Universitetsforlaget, 1980.

- Lukač, Dušan. Treći rajh i zemlje jugoistočne Evrope, Vol. II, 1937-1941. Beograd: Vojnoizdavački centar, 1982.

- Ljotić, Dimitrije. Sabrana dela, Vol. I-XII. Beograd: Nova iskra, 2001.

- Magazinović, Hrvoje. Kroz jedno mučno stoljeće: Sjećanja. Valjevo: Novo videlo, 2009 (2nd expanded edition).

- Martinović-Bajica, Petar. Milan Nedić. Čikago: Nikola Pašić, 1956. 
- Matić, Milan B. Štampa u Srbiji u Drugom svetskom ratu 1941-1944. Beograd: Ph. D. mscr., 1990.

- Milićević Nataša, Dušan Nikodijević, (eds.). Svakodnevni život pod okupacijom: Iskustvo jednog Beograđanina 1941-1944. Beograd: INIS, 2011.

- Milosavljević, Olivera. Potisnuta istina. Kolaboracija u Srbiji 1941-1944. Beograd: Helsinški odbor za ljudska prava u Srbiji, [2006.].

- Milošević, Slobodan D. Nemačko-italijanski odnosi na teritoriji okupirane Jugoslavije 1941-1943. Beograd: ISI, 1991.

- Mussolini, Benito. Fascismo, in: www.tereccani.it/enciclopedia/fascismo_ (Enciclopedia italiana)

- Nikolić, Kosta. „Nemačka ratna propaganda u Srbiji 1941-1944“. Jugoslovenski istorijski časopis, 1, (1997), 117-128.

- Nikolić, Kosta. Strah i nada u Srbiji 1941-1944: Svakodnevni život pod okupacijom. Beograd: Zavod za udžbenike i nastavna sredstva, 2002.

- Nikolić Kosta, Bojan B. Dimitrijević. Danilo Gregorić i 25. mart 1941. Beograd: ISI, 2007.

- Nedić, Milan Đ. Desna Srbija: Moja reč Srbima 1941-1944: Izabrani ratni govori. Beograd: Slobodna knjiga, 1996.

- Nikolova, Maja. Zavod za prinudno vaspitanje omladine u Smederevskoj Palanci 1942-1944. Beograd: Pedagoški muzej, 2010.

- Nolte, Ernst. Die Krise des liberalen Systems und die faschistischen Bewegungen. München: Piper, 1968.

- Parežanin, Ratko. Drugi svetski rat i Dimitrije V. Ljotić. Beograd: A. Z. Jelić, P. Janković, 7510 [2002.].

- Payne, Stanley G. A History of Fascism 1914-1945. London, New York: Routledge, 2003.

- Petranović, Branko. Srbija u Drugom svetskom ratu 1939-1945. Beograd: Vojnoizdavački i novinski centar, 1992.

- Pivac, Marko. Koraci u noći. S. 1. : Novo videlo, [2002].

- Propadović, Milutin. D. V. Ljotić, Zbor i Komunistička partija Jugoslavije 1934-1945: Prilozi za istinu o JNP Zbor. Beograd: Iskra, 2012.

- Schlarp, Karl-Heinz. Wirtschaft und Besatzung in Serbien 1941-1944: Ein Beitrag zur nationalsozialistischen Wirtschaftspolitik in Südosteuropa. Stuttgart: Franz Steiner Verlag, 1986.

- Simić, Miodrag. „Škole u Beogradu za vreme okupacije od 1941. do 1944. godine“. Godišnjak grada Beograda, 21, (1971), 75-117.

- Stefanović, Mladen. Zbor Dimitrija Ljotića 1934-1945. Beograd: Narodna knjiga, 1984.

- Šabo, Federiko. Italija (1918-1948). [Beograd: Nolit, 1978].

- Škodrić, Ljubinka. Ministarstvo prosvete i vera u Srbiji 1941-1944: Sudbina institucije pod okupacijom. Beograd: Arhiv Srbije, 2009.

- Škodrić, Ljubinka. „Odnos nemačkog okupatora prema domaćim saradnicima u Srbiji 1941-1944“. Oslobođenje Beograda 1944, Zbornik radova. Beograd: INIS, 2010, 82-94. 
- Vojčić, Dragoslav. „Školstvo u okupiranoj Srbiji tokom Drugog svetskog rata“. Nastava i vaspitanje, 22, (1973), 234-248.

- Vojnović, Aleksandar. NDH u Beogradu. Zagreb: Naklada Pavičić, 1995.

- Wuescht, Johann. Jugoslawien und das Dritte Reich: Eine dokumentierte Geschichte deutsch-jugoslawischen Beziehungen von 1933 bis 1945. Stuttgart: Seewald Verlag, 1969.

- Žorž, Branislav A. Zavod u Smederevskoj Palanci: Ostrvo spasa ili robijašnica. Beograd: Novo videlo, 2006.

- Žujović, Mladen J. Ratni dnevnik, II: Jugoslavija u Drugom svetskom ratu. Vrnjačka Banja: Interklima-grafika, 2004. 
ZORAN JANJETOVIĆ, PhD, Principal Research Fellow

Institute for Recent History of Serbia

Belgrade, Republic of Serbia

e-mail: vanilica@ptt.rs

\title{
DIMITRIJE LJOTIĆ AND WORLD WAR II
}

\begin{abstract}
Summary
The paper deals with the activity of the controversial right-wing politician Dimitrije Ljotić during the German occupation of Serbia 1941-1944. Ljotić was the leader of the fascist-like movement Zbor that strove to reform Yugoslavia along the authoritarian lines. Its salient features were anticommunism and anti-Semitism. These features, especially anti-Semitism, became more prominent during the late 1930s. Ljotić aimed his political and propaganda activity at keeping Yugoslavia out of the war. To that aim, he suggested a number of authoritarian reforms. Under German occupation the movement was the only that was permitted to operate. Although he shared some of the ideological views of the Nazis, Ljotic collaborated with them in the interest of his people, as he believed. He put the blame for WWII on the Jews who according to him, strove for world dominance. Thus he did nothing to prevent deportation and extermination of his Jewish fellow-countrymen and he indulged in Jew-baiting until the very end of the war. No less rabid was his anti-communism. He fought it ideologically through the press, and with weapons - through the Serbian Volunteer Corps under Zbor's domination. He also set up a penitentiary re-educational institution for communist youths. In that way he showed he was not a low-brow anti-communist who believed only in violence. Although often termed eminence grise of the collaborationist regime, the extent of his actual influence remains disputed. It seems it was substantial, but not overwhelming: he did help set up the collaborationist governments and had influence on them, but it was not decisive. His adherents were also persecuted by the German and Serbian police, and only part of higher officials were members of the Zbor. The realm of education was in the hands of Ljotić's opponents. He helped install his relative Milan Nedić as prime minister, but he could not influence him on many points and the rivalry between the two men was obvious. Nedić's plan for reorganization of Serbia along authoritarian lines did not bear the Zbor's features but was rather a copy of the Italian political system. By wanting to help his people under occupation, Ljotić fell victim to his own limitations that prevented him from realizing the true meaning of WWII and forced him to put up with people and phenomena that he had so severely criticized before the war.
\end{abstract}

KEYWORDS: Dimitrije Ljotić, Zbor, WWII, occupation, Jews, Germans, Milan Nedić 